\title{
O CORPO DO DEMÔNIO
}

\author{
Sergio Rizo \\ sergiorizo@sergiorizo.com
}

\section{Resumo}

O corpo humano, como espaço de significações e saberes, inscreve-se, definitivamente, na ordem do dia. Como sujeito e como objeto, nos diversos campos do conhecimento humano, na arte, na ciência, na filosofia e como símbolo histórico de notável presença, a questão do corpo e as suas representações são fundamentais no pensamento ocidental desse século que se inicia. Poderia-se dizer até que se trata de uma obsessão contemporânea, não fosse a longa história que existe por detrás das representações corporais. Espaço da expressão individual com significados coletivos, "lugar da biologia, das expressões psicológicas, dos receios e fantasmas culturais, o corpo é uma palavra polissêmica, uma realidade multifacetada e, sobretudo, um objeto histórico".

A representação do corpo humano têm sido um tema central na arte ocidental. Em consonância com esta tradição e desde os seus primórdios, o cristianismo utilizou um sistema de representações com base no corpo humano que enfatizou a relação problemática entre o corpo e a alma. A ambigüidade do corpo cristão dividido entre as forças do bem e do mal, premido entre o Paraíso e Inferno, deu origem a uma vasta produção de representações e metáforas relacionadas ao corpo humano na história das artes visuais e literárias. O foco de interesse deste capítulo é a representação dos corpos demoníacos. Mais especificamente, do corpo do Demônio, o grande opositor de Deus. Nele, Luther Link $^{2}$ me forneceu significativos subsídios sobre a história da representação do Demônio na arte. Segundo ele, a figura do Demônio, em termos de sua significação intrínseca, se elaborou como um epifenômeno nas suas representações, enredando em variados papéis, muitas vezes dentro de um mesmo contexto histórico. A serpente, por exemplo, que no século XIV, tanto pode simbolizar a sutil sedutora Eva no Éden, quanto a terrível punidora dos ladrões no Canto XXIV do Inferno de Dante. Neste sentido, o Demônio foi sempre uma representação marcada pela ambigüidade, destituída de profundidade, deexistência servil, e ao qual coube, sentado no seu trono em brasas, cumprir a função principal de punidor de Deus no Inferno ${ }^{3}$.

\section{Abstract}

The human body, as a space of meanings and knowledge, falls definitely on the agenda. As subject and object, in various fields of human knowledge, art, science, philosophy and as a historical symbol of remarkable presence, the question of the body and its representations are fundamental in western thought of the century to come. One could

${ }^{1}$ BERNUZZI DE SANT’ANA, Denise. Políticas do Corpo, São Paulo, Estação Liberdade, 1995, p.12.

2 LINK, Luther. O Diabo: A máscara sem rosto, São Paulo, Ed. Schwarcz.

Esta função é desempenhada exemplarmente nas representações dos infernos dos Juízos Finais, sobretudo no período entre o século XII e o XVI. 
even say that it is a contemporary obsession, was not for the long history that lies behind the body representations. Space for individual expression with collective meanings, "place of biology, psychological expressions, fears and cultural ghosts, the body is a polysemous word, a multifaceted reality and, above all, a historical object." The representation of the human body has always played a central role in Western art. In line with this tradition and since its beginning Christianity has used a system of representations oriented around the human body to emphasize the problematic relationship between the physical body and the soul. The ambiguity of a Christian body fought over by the opposing forces of good and evil, wrenched between Heaven and Hell, gave origin to a vast number of representations and metaphors relating to the human body throughout the history of the written and visual arts.

The focus of this chapter is the representation of demonic bodies. More specifically the Devil's body, the great opponent of God. In it, Luther Link provided me significant subsidies on the history of the Devil representations in art. According to him, the figure of the Devil, in terms of its intrinsic significance, was drafted as an epiphenomenon in its several representations, tangling in varied roles, often within the same historical context. The snake, for example, that in the fourteenth century, both can symbolize subtle seductive Eve in Eden, as the terrible punisher of thieves in Canto XXIV of Dante's Inferno. In this sense, the Devil was always a representation marked by ambiguity, devoid of depth, of a servile existence, and which fit, commanded by God and sitting on his throne on fire, to keep the main function of executioner in Hell.

\section{CONSTRUÇÃO DO CORPO DO DEMÔNIO.}

A iconografia diabólica da Europa medieval se origina de três fontes principais: o extremo oriente, a antiguidade clássica e o Islã. Estas três culturas contribuíram para o nascimento e desenvolvimento do diabo cristão nas suas variadas aparências, tendo sido representadas em diversas formas de arte, tais como a pintura, gravura, escultura, miniaturas e tapeçarias, desde a era romanesca. Elementos nãoeuropeus e pré-cristãos, combinados ao amor pelo fantástico e irracional da Idade Média, ajudaram a tornar o Demônio um dos símbolos mais relevantes do Medievo. A mistura de diversas culturas e tradições originou a fauna fantástica que teve seu apogeu com os distúrbios do fim do primeiro milênio cristão. De fato, a pobreza endêmica, a fome, as pestes e as guerras que aconteceram na Europa no período compreendido entre os séculos X e XII, que pareciam confirmar as assustadoras palavras do Apocalipse quanto à libertação de Satã, ajudaram a conferir uma aura de puro terror ao inimigo de

Deus. Os efeitos desequilibrados de um precário presente e de um futuro incerto 
introduziram na iconografia religiosa, representações monstruosas e bestiais do Demônio.

Embora essas representações fossem extremamente variadas e mutáveis, elas compunham um sistema de imagens que tinha por função principal moderar as tendências politeístas do cristianismo medieval, concentrando a multiplicidade das figuras à unidade do Inimigo de Deus. E eis o paradoxo: O cristianismo sempre evitou identificar na oposição demoníaca a Deus uma vigência dualista. Mas apesar dos seus esforços, não conseguiu impedir "o desenvolvimento de uma faceta, sem dúvida vivida de forma muito sensível, que dá ao Diabo um vasto campo de autonomia". 4

Mesmo assim, o Demônio provou ser uma síntese simbólica extremamente eficaz na imposição do cristianismo em meio a culturas possuidoras de inúmeras entidades anímicas e politeístas.

O cristianismo, de um princípio marginal, foi se estruturando como uma religião expansionista, e nas suas origens hebraicas, pode residir a causa do constante processo de demonização das divindades alheias:

As repetidas beligerâncias que compõem o processo de expansionismo dos povos da Antiguidade tem como tradução, numa esfera religiosa, a assimilação dos deuses dos inimigos a entidades malignas, pois estes pertencem a seus povos e atuam como representantes destes. Testemunho dessa situação peculiar são as menções - freqüentes na Antiguidade - a guerras, não entre reis ou povos, e sim entre deuses. O deus vencedor subjugará e se apropriará do território, submetendo as divindades nele contidas. O povo vencido reagirá, então, num processo de retaliação, colocando a responsabilidade de seus males no deus vencedor. A esse caráter maligno latente a posterior expulsão do invasor agregará uma condição de inferioridade - a de divindade caída -, colocando-se explicitamente o antigo deus invasor como um espírito do Mal, cuja esfera de atuação retrata as desgraças anteriormente vividas. ${ }^{5}$

A gestação do cristianismo deu-se no seio das tradições religiosas hebraicas. No seu início, constituía um monoteísmo que proibia a idolatria. Os hebreus demonizavam os deuses estrangeiros. A preocupação maior era com a sobrevivência de

4 SCHMITT, Jean-Claude \& Jacques Le Goff. Dicionário Temático do Ocidente Medieval, Editora da Universidade do Sagrado Coração, Bauru, 2002, p. 320.

${ }^{5}$ NOGUEIRA, Carlos Roberto F. O Diabo no Imaginário Cristão, São Paulo, EDUSC, 1986, p.7. 
uma nação, e o Antigo Testamento não faz referência ao Demônio. É só a partir do Novo Testamento que a preocupação individualista de salvação da alma no Além se impõe no dogma religioso.

A falta de uma tradição pictórica específica para a figura do Demônio e a confusão das iconografias constantes nas fontes literárias, que misturavam os diferentes sentidos do Diabo, Satã, Lúcifer e Demônio, deveu-se à inexistência de uma imagem unificada do Demônio e da sua errática iconografia.

Satã principia sua história no poema do sofrimento de Jó, no Antigo Testamento, como o Acusador (o termo hebreu ha-sâtân), que propõe a Deus a prova de fé de Jó ${ }^{6}$. O Satan, precedido do artigo o, não é um nome, é um posto, seja de inspetor, seja de promotor do conselho de Deus. Originalmente, portanto, não significa o Diabo como se conhece hoje em dia.

O Diabo, por sua vez, é chamado de diabolus nos Evangelhos de Lucas e Mateus. Essa palavra grega significava acusador ou difamador; e foi traduzida para o latim como diabolus. ${ }^{7}$

No cativeiro da Babilônia e no contato com as entidades caldéias é que vai articular-se a figura de Lúcifer $^{8}$, associado ao rei da Caldéia: faz sua primeira aparição em Isaías ${ }^{9}$, onde o profeta escarnece da queda do rei do poder, perguntando: Como caíste do céu, ó Hellel, estrela da manhã? - que a Vulgata traduz por Lúcifer, qui mane oriebaris, tornando o Deus caído chefe das legiões rebeldes. Mais tarde, Santo Agostinho reforçou essa tendência a equivaler Lúcifer ao Demônio, com vistas a combater os argumentos dos maniqueus sobre a dualidade cristã. Lúcifer não era um nome, significava “o que leva a luz". Nada mais era do que o planeta Vênus, chamado de estrela da manhã. O termo valeu até para exaltar Dante, como o fez Shelley, em Defence of Poetry, ao escrever "o congregante dos grandes espíritos que presidiram a ressurreição do saber, o Lúcifer excede em brilho as estrelas mais radiantes". ${ }^{10}$

Demônio é um termo derivado de dáimon, palavra grega que originalmente designava uma divindade. Posteriormente, e num sentido mais comum, indicava um

\footnotetext{
${ }^{6}$ LINK, Luther. O Diabo: A Máscara sem Rosto, São Paulo, Editora Schwarcz, 1998, p. 24.

7 Idem, p. 24.

8 Ibidem, p. 28.

9 Isaías $(14,12)$ in: Bíblia Sagrada, Edição Barsa, 1965.

${ }^{10}$ Link, Luther. op., cit, p. 28.
} 
espírito mediador entre deuses e homens; Platão o chama de amor no Banquete ${ }^{11}$, para Sócrates, são homens bons e sábios, e Shakespeare o equivale a um gênio, ao espírito humano, passível inclusive de elogio, na peça Antônio e Cleópatra. ${ }^{12}$

A multiplicidade das suas designações, Satã, Diabo, Lúcifer e Demônio, e os vários sentidos e interpretações associados, o acusador, o difamador, a estrela da manhã, a divindade e o espírito mediador, farão com que, somente a partir da Idade Média, e sob o jugo doutrinário da Igreja, seja desenvolvido um programa iconográfico e educativo de suas imagens com uma certa coerência. Nesse sentido, o Demônio foi um instrumento didático de propagação da fé, pois, com seu antagonismo, reforçava o lado positivo e bom de Cristo, dos Santos e de Deus. Sua iconografia foi organizada e produzida nos mosteiros no século XI, sob a orientação dos monges, "que viram nele uma potência feroz e violenta". 13

A pedagogia medieval, por assim dizer, objetivou instruir, explicar e reforçar a crença cristã, por meio dos sermões, encenações teatrais, vitrais, mosaicos, afrescos e esculturas. O significado era determinado por intermédio da iconografia, normalmente planejada pelas igrejas locais e executadas pelos seus artistas. Na Idade Média, alterar uma convenção pictórica podia ter implicações políticas e teológicas. Era um assunto muito sério, mas as normas das representações se aplicavam com mais rigor nas imagens de Cristo, Maria e dos santos em geral. A iconografia do Demônio, muitas vezes em função da sua própria natureza variada, tinha mais possibilidades figurativas, e as suas representações se faziam diferentes, às vezes, dentro de uma mesma obra, como é o caso do Juízo Final de Fra Angélico, no convento de São Marcos, em Florença. "Alguns dos diabos têm chifres, outros, não; uns têm rabo, outros, não; há os alados e os não-alados, os peludos e os glabros, uns com cara de cachorro, e outros de gato" ${ }^{14}$. A instabilidade no trato da imagem do Demônio advinha do fato de ele nunca ter tido uma iconografia fixa de referência, pois a teologia oficial sempre evitou uma abordagem mais detalhada e profunda do seu significado, com temor de se acentuar um conteúdo potencial de dualismo.

11 Idem, p. 25.

${ }^{12}$ LINK, Luther, op., cit, p. 25.

13 Idem, p. 55.

14 Ibidem, p. 47. 
A escolástica comumente utilizava quatro níveis de significação para explicar a Bíblia: literal, moral, alegórico e anagógico (místico). Um exemplo prático dessa classificação seria a cidade de Jerusalém, que sob o ponto de vista literal significaria a cidade física na Palestina; no ponto de vista moral, a igreja de Cristo, no ponto de vista alegórico, a cidade do Paraíso e sob o ponto de vista anagógico, a alma cristã.

Link considera bastante discutível a utilização estrita desses princípios escolásticos na execução das imagens religiosas, argumentando que essas obras de arte tinham um aspecto calculadamente didático de educação da massa iletrada. Assim, as imagens deviam conter um simbolismo mais simples que ilustrasse, de forma mais direta e compreensível, as mensagens dos sermões para a população iletrada que freqüentava as igrejas locais. Ele propõe a técnica medieval, mais simples, das correspondências simbólicas. E, em particular, um tipo de simbolismo chamado de realismo figural. Esse simbolismo relaciona um conjunto de correspondências e analogias entre os eventos constantes no Antigo Testamento e no Novo Testamento. Um exemplo seria a analogia da captura de Sansão pelos filisteus (Antigo Testamento) com a prisão de Cristo pelos romanos (Novo Testamento). Link considera a imagem de Satã, como o símbolo do mal e o oponente teológico de Cristo, por demais abstrata para ser convincente nas representações das artes visuais da Idade Média e do Renascimento. Conclui que "em quase toda arte medieval e renascentista o Diabo foi um sinal, jamais um símbolo artístico" $"$.

Na baixa Idade Média, o medo do Inferno e do Demônio aterrador, "serve como instrumento de controle social e de vigilância das consciências, incitando à transformação das condutas individuais". ${ }^{16}$ O Demônio fica, assim, intimamente relacionado ao Inferno, sentando-se, magistralmente, no seu centro. Passa a significar o inverso da majestade do rei terreno, que em última instância, é o representante da soberania de Deus. O esquema da representação é claro, porque as imagens do Demônio-rei "veiculam uma noção hierárquica do mundo infernal, calcada na da soberania real". ${ }^{17}$ Ao banquete do rei corresponderá a devoração de almas pelo

${ }^{15}$ LINK, Luther, op., cit, p. 202.

16 MUCHEMBLED, Robert. Uma História do Diabo: Séculos XII-XX, Rio de Janeiro, Bom Texto, 2001, p. 36.

${ }^{17}$ Idem, p. 38. 
Demônio, pois este, comendo as suas vítimas, apareceu pela primeira vez no Juízo Final de Torcello, no século XIII, perdurando por séculos depois de Giotto.

O Demônio entronizado é o monarca do esgoto e da imundície, comentado pelo Papa Leão I.

Mas em termos da sua aparência, a tendência generalizada já a partir do século XIII, é no sentido da sua animalização. Um rei do Inferno sim, mas de realeza monstruosa, horrível e corrompida, que se impõe pela brutalidade da sua forma bestial. Essa imagem fazia parte da propaganda produzida pelos doutos e difundida pelos criadores, escritores e eclesiásticos em seus sermões ou em seus contatos com os fiéis.

Não se deve esquecer, porém, de que em todas as épocas e paralelamente, ocorre o Demônio ludibriado e grotesco, das representações sacras, carnavalescas e do folclore, mais de acordo com o gosto e a vivência populares. O clero sempre se preocupou em impor uma imagem terrível do Demônio sobre o seu aspecto cômico e grotesco, com receio da imagem perder a sua eficácia, enquanto símbolo religioso partícipe da didática do medo. No fundo, o Demônio cristão unificado não passou de um mito monástico, de uma obsessão engendrada no recolhimento religioso e reflexivo, parte da iniciação litúrgica dos monges nos monastérios medievais. O Demônio representou uma conveniência simbólica na catequese cristã, pois serviu como um excelente contraste à bondade de Cristo - para ser sempre derrotado por Ele - tendo sido extremamente útil no combate às heresias internas dos primeiros tempos do cristianismo, e nas externas, desde valdenses e cátaros até a reforma protestante. Num segundo momento, a Igreja não vacilou em usá-lo como o responsável pelas mortes dos inúmeros infelizes queimados pela infame inquisição. Como se vê, o Demônio foi um curinga debaixo da manga do braço milenar da Igreja, pronto para ser sacado e usado para todos os tipos de objetivos, sempre sob a justificativa de ser o grande inimigo de Deus e da humanidade.

Um caso curioso de divisão simbólica, por assim dizer, é o da personificação do Inferno nas encenações de mistérios medievais. A temática é relativa à iconografia da boca do Inferno, que podia representar uma força com vontade própria separada do Demônio (o tormento do Inferno), um receptáculo divino de contenção do Demônio (o Apocalipse), ou um instrumento do Demônio (o Juízo Final). No episódio do tormento do Inferno, este, personificado, considera Satã um manancial de problemas. 
Possui uma consciência, e deveras crítica, pois chega a repreender Satã após Cristo a ter forçado a abrir para libertar as almas que lá estavam cativas. Na cena predileta dos autores de mistérios, o Inferno fala, zanga-se com Satã culpando-o pela vinda de Cristo: "Veja só o que você fez, imbecil!"18

\section{O DEMÔNIO E A ARTE: A SERPENTE}

Em termos das artes, o Demônio estava quase totalmente ausente das imagens cristãs até o século IX. A partir daí, consoante com a didática do medo da Igreja e do programa de expansão do cristianismo, suas figurações vão progressivamente conquistando espaço no imaginário coletivo dos povos cristãos da Europa. No período compreendido entre o século XII e XVI, as representações do Demônio e do Inferno atingem o seu ápice, seja em função da qualidade, como também da quantidade das imagens produzidas. Foram nesses quatro séculos que a iconografia do Demônio se fixou no imaginário cristão e em que se definiu o conjunto das suas atribuições. Essas, se mostraram sempre estar a serviço de Deus, e coincidentemente, atendiam também aos interesses do clero.

A classificação das principais iconografias do Demônio pode ser resumida segundo a ordem das suas representações temáticas. Pierre Francastel ${ }^{19}$, por exemplo, propõe a divisão segundo a quádrupla tradição teológica e figurativa, das séries iconográficas distintas do Demônio, a elas relacionando as mais freqüentes representações:

A possessão, que envolveu as representações dos diabretes negros e dos gênios alados; O Apocalipse, que reuniu as iconografias do dragão, do Demônio acorrentado e da queda dos anjos rebeldes; A tentação, onde a serpente reina absoluta; e o Inferno, em que o gigantesco e monstruoso Demônio medieval, peludo e escuro, chamado de o rei das sombras senta, pachorrento, no seu trono de imundícies. É uma classificação conveniente para um estudo que analise o conjunto das iconografias do Demônio nos

18 Link, Luther. O Diabo: A Máscara sem Rosto, Editora Schwarcz, São Paulo, 1998, p. 90.

19 FRANCASTEL, Pierre. A Realidade Figurativa, São Paulo, Perspectiva, 1973. 
episódios bíblicos e na história do cristianismo, mas é de vital importância manter em mente que o contexto dessas imagens é crucial na sua compreensão.

Decidi considerar como a referência central das representações do Demônio, o aglomerado das iconografias monstruosas, principalmente a categoria dos compósitos medievais, por se relacionar mais diretamente aos monstros humanóides e metamórficos do Inferno de Barlowe. O composto monstruoso pressupunha a fusão do corpo humano com o corpo animal. E a simbologia animal na Idade Média era fundamental na formulação do corpus imaginário das criaturas fantásticas e infernais. Mas as iconografias desses demônios não eram exclusivas do mundo inferior, pois se estendiam aos demais episódios bíblicos que articularam o papel dos seres demoníacos e animalescos, nas representações ocidentais do Inferno. $\mathrm{Na}$ verdade, os corpos demoníacos constituíram uma espécie de moeda de troca no comércio das iconografias medievais, visto que as contaminações simbólicas e as migrações de categorias eram muito comuns nos regimes das suas representações. A serpente, por exemplo, principia a sua história no dragão do Apocalipse do cristianismo primitivo, e posteriormente, assume características humanas no Medievo, para então retornar ao seu estado natural de réptil nas representações demoníacas da era iluminista.

Considerando as iconografias demoníacas no seu conjunto, é a partir do Renascimento que as características animalescas começaram a ceder espaço para representações mais humanizadas, sob a influência de um impulso em direção ao belo clássico, e na emergência da experimentação científica. Com o advento do iluminismo, as representações monstruosas migraram para os gêneros grotescos do Inferno e para a sátira. $\mathrm{O}$ pensamento científico substituiu progressivamente a filosofia teológica e a Igreja, como instituição de poder na gestão das imagens religiosas, ficou relegada a um papel secundário, com o surgimento do Estado moderno. No romantismo e no simbolismo, a ressurgência dos temas infernais deu-se sob a égide da figura de Satã, elevado à condição máxima do modelo exemplar da beleza maldita baudelairiana. Foi somente no surrealismo que as representações infernais de monstros e compósitos fabulosos tiveram uma renovação no seu repertório de imagens, com o fascínio mórbido da animalidade e da beleza convulsiva de George Battaile e André Breton.

$\mathrm{Na}$ atualidade, a permanência de algumas dessas representações demoníacas medievais se faz sentir sobretudo no campo da ilustração da arte fantástica e da ficção- 
científica, especialmente nas representações de seres fabulosos que fundem o orgânico, o mecânico e o eletrônico, dando origem à categoria dos corpos ciborgues e dos monstros interplanetários.

A iconografia do início da Idade Média representa o Demônio como um animal mal adaptado ao vôo, rastejante e ardiloso: a serpente que tenta Adão e Eva. Este réptil é o símbolo por excelência da tentação diabólica, e o episódio bíblico tem lugar no Jardim do Éden, conforme consta no Gênesis. ${ }^{20}$ Não se sabe ao certo como era a serpente antes, pois só se toma conhecimento da sua aparência depois da maldição lançada sobre ela por Deus. Diz-se, porém, que era o mais astuto de todos os animais da terra. Além de ter tido uma postura ereta, perdida depois da praga divina. Lobos e raposas também sempre foram animais bastante conhecidos pela sua astúcia, mas talvez a serpente tenha se tornado símbolo do mal por outras razões, além da esperteza. A serpente é predadora venenosa que se enrosca no corpo das suas vítimas num íntimo abraço mortal, sufocando-as, e depois as devora, por inteiro, lentamente, sem despedaçá-las.

Outra característica muito propícia à simbolização é a do hipnotismo das vítimas, provocado pelos movimentos ondulados do corpo da serpente. Uma propriedade similar a esta, consta nos bestiários medievais ${ }^{21}$, como pertencente a uma serpente denominada Scitalis, possuidora deste nome por causa da variedade do colorido das suas escamas, que de tão fascinante e encantador, chega a paralisar e a matar o homem que para ela olhar. ${ }^{22}$

Existe ainda o encantamento do silvo da serpente, que se traduz pelo verbo deceptoria - a sedução pela palavra, o cochicho encantador no ouvido de Eva.

O fascínio, o ardil e a sedução são as armas usadas pelo Demônio para tentar Eva. Na sua representação na arte, o Demônio assume a forma de uma serpente com a cabeça de uma bela mulher, enroscada elegantemente na Árvore do Conhecimento do

\footnotetext{
${ }^{20}$ Gênesis (3,13), Bíblia Sagrada, Edição Barsa, 1965.

21 Os bestiários medievais ainda relacionam quatro outros tipos de serpentes: o Draco, ou Dragão, a maior de todas as serpentes, sua maior força residindo nos violentos golpes e apertões do seu rabo, o Basilisco, que como a Górgona grega mata o homem só pelo seu olhar, a Áspide ou Víbora, que injeta e espalha o veneno com a sua picada, e a Amphivena, que tem uma outra cabeça no rabo, rola como um aro e é a única serpente que suporta bem o frio, e inclusive hiberna. Para um aprofundamento no assunto, consultar. A Medieval Bestiary, J. L. Schrader, The Metropolitan Museum of Art, New York, 1986.

22 SCHRADER, J. L. A Medieval Bestiary, The Metropolitan Museum of Art, 1986, p. 49.
} 
Bem e do Mal. É o caso da cena da tentação pintada por Masolino da Panicale, ${ }^{23}$ em 1424, no afresco da Igreja de Santa Maria del Carmine, em Florença. O Demônioserpente-mulher de Masolino assume uma atitude protetora de Eva, pois se posiciona acima da sua cabeça, com uma expressão benevolente na face. Eva, por sua vez, abraça a Árvore, representada fina e com poucos galhos. O detalhe relevante é que o braço esquerdo de Eva se enrosca no tronco fazendo um arco serpenteante, complementar ao do corpo do Demônio-serpente-mulher. É como se a serpente já tivesse se enroscado na sua vítima, e esta, assume a forma do corpo daquela. A transferência simbólica se completa materialmente na representação: a serpente possui a bela cabeça da mulher, e a mulher o movimento espiralado da serpente. Os dois corpos se unem nesse serpentear hipnótico e ondulante do pecado. Só falta Adão, que fascinado (hipnotizado) pela beleza do complexo Demônio-serpente-mulher-Eva, tem a palma da sua mão esquerda voltada para cima, num gesto típico de aceitação.

Na tentação de Eva, o Demônio assume ainda a face de uma mulher, desta feita enfatizando o fato dela ser virgem e, com isso, a duplicidade da forma física (com Eva, que também é virgem) se transforma no signo da duplicidade moral. E a dupla serpenteEva se dirige contra o homem, no caso, Adão.

Vê-se então que um simbolismo fundamental no cristianismo é o que relaciona o Demônio à mulher. Trevisan sustenta uma misoginia histórica e própria da concepção sexual do século XI, que se evidencia na interpretação dada ao referido trecho bíblico. Trevisan cita Fílon de Alexandria, autor judeu e contemporâneo de Jesus, que escreveu: "Para a mulher, a serpente é o gozo que se torce e se enrola, procurando no corpo a saída, acomodando-se em sinuosidades e fendas em cada um dos sentidos". ${ }^{24}$ A consciência do desejo sexual, da atração e da repulsa pelo corpo feminino, por parte dos monges (eram eles que elaboravam os programas iconográficos que iriam orientar na elaboração das imagens religiosas), fica clara quando, no século IV, São João Crisóstomo, diz:

23 Pintor italiano, nascido em 1413 e falecido em 1450. Foi discípulo de Lorenzo Ghiberti, estudou em Roma e ganhou fama ao pintar a História da Vida de São Pedro em Florença.

${ }^{24}$ TREVISAN, Armindo. O Rosto de Cristo: A Formação do Imaginário e da Arte Cristã, Porto Alegre, Editora Age, 2003, p. 82. 
(...) Quantas vezes, por contemplar uma mulher, sofremos mil maleficios, voltando para casa e nutrindo um desejo fora do comum, e sentindo angústia por muitos dias. (...) A beleza da mulher é a maior das armadilhas. Ou antes, não a beleza da mulher, mas um olhar sem castidade. $^{25}$

A assimilação das características da serpente por Eva tem como antecedentes na arte a Eva de Autun, de 1135, feita por Gislebertus, no dintel românico da porta da Basílica de Saint-Lazare, relevo no qual a mulher adota a forma da serpente, numa flexuosidade acentuadamente erótica, horizontal e que se transmite a toda vegetação do Jardim do Éden (as plantas e as árvores assumem um formato serpenteante).

A crença medieval via ainda a mulher como a personificação da malicia e falsidade (como no mito grego de Pandora): ela leva o homem ao pecado, e transforma a serenidade humana num pesadelo miserável.

No entanto, no fim do século XVII, a serpente realista, zoomórfica, relata Nona Flores, "se torna a forma dominante nas representações, refletindo a mudança do interesse medieval na natureza como uma fonte de alegoria moral e simbólica, para o moderno conceito da natureza como uma ciência exata". ${ }^{26}$

A contrapartida a esta misoginia medieval e bíblica que atribuiu o papel da tentação à mulher, se mostra quase um século depois na pintura de Adão e Eva do alemão Hans Baldung ${ }^{27}$. De acordo com a descrição de Link:

Eva segura a maçã; Adão envolve um de seus seios com uma das mãos e acaricia-lhe a coxa com a outra. Em uma espantosa inversão, Baldung faz de Adão o sedutor, em vez de Eva. Os cabelos despenteados de Adão sugerem os chifres do Diabo (mal se nota a pequena serpente no canto superior esquerdo). Senso de pecado, vergonha e culpa não tem lugar nessa pintura de duas pessoas unidas de maneira confiante e experiente no prazer do amor sensual. Se esse Adão de Baldung for o Diabo, essa composição original faz lembrar o Diabo de Blake, personificando o prazer sexual. ${ }^{28}$

De fato, creio ser esta representação uma surpreendente inversão na tendência medieval de destinar a imagem feminina os atributos demoníacos de Satã. O Adão de

\footnotetext{
${ }^{25}$ Idem, p. 85.

${ }^{26}$ FLORES, Nona C. Animals in the Middle Ages, New York, Routledge, 1996, p. 174.

27 Pintor alemão, nascido em 1480 e falecido em 1540. Foi notável também, como gravador de madeiras.

28 LINK, Luther. O Diabo: A Máscara sem RostoSão Paulo,, Editora Schwarcz, 1998, pp. 160-161.
} 
Baldung é o Demônio, ou pelo menos por ele está absolutamente possuído. Note-se a malícia e a lascívia do seu olhar antes de provar a maçã, se é que já não o fez. Mas se bem observado, verificar-se-á que o braço de Eva enrosca na Árvore do Conhecimento, a mesma em que se encontra a pequena serpente (e as serpentes menores, que mal se notam, costumam ser extremamente venenosas). Os seus cabelos caem lateralmente em madeixas serpenteantes. Seguindo a sua direção superior, depara-se com os olhos de Eva e os de Adão, juntos, colados, formando uma linha sinuosa, como uma serpente. Enfim, a imagem toda se encontra demonizada, com Adão e Eva vítimas da ação do veneno do Demônio (e o que é a tentação se não um envenenar-se de desejo?) e este aspecto é um indicador de que no século XVI, a idade em que as feiticeiras encarnam Satã, o demoníaco parece se expressar na arte, numa sexualidade mais refinada e sensual. É o Satã francamente humanizado, fruto de um processo lógico de representação da interiorização demoníaca, iniciado no século XV, quando as hordas infernais subiram a superfície da terra. A imagem em questão também aponta para o desenvolvimento de uma iconografia de Satã não só semelhante ao de Blake, mas ao modelo maior do Demônio ambíguo, sábio, sensual, malicioso, aristocrático e decadente, típico do romantismo dos séculos XVIII e XIX. Um último detalhe curioso: repare-se no tecido diáfano que cobre o sexo de Eva e que representa o toque luxurioso desse verdadeiro retrato da tentação sensual. ${ }^{29}$

\section{IMAGENS DO DEMÔNIO}

As imagens dos demônios de asa de morcego, segundo Jurgis Baltruisatis, derivaram basicamente da arte chinesa do período Chou, sendo que suas primeiras representações na arte européia datam do séc. XIII ${ }^{30}$. De tais arquétipos, os artistas góticos formaram suas representações demoníacas, criando um repertório de composições de símbolos horrorizantes. Link relativiza esta influência sustentando que, embora isso possa ter sido possível, ele acredita que a iconografia das asas de morcego

29 No Gênesis $(3,7)$, consta que, logo após terem comido o fruto proibido, Adão e Eva, ao tomarem conhecimento da sua nudez, coseram, umas com outras, umas folhas de figueiras, fazendo umas cintas para cobrir seus sexos, uma vez que passaram a ter vergonha de andarem nus.

${ }^{30}$ BALTUSAITS, Jurgis. Le Moyen Age Fantastique, Paris, Armand Colin, 1955, p. 151 - 167. 
tenha se originado nos afrescos de São Francisco em Assis, que Giotto fez antes de 1300 usando apenas sua imaginação. Argumenta inclusive que Dante foi por ele influenciado na sua representação literária do Demônio na Divina Comédia.

$\mathrm{Na}$ Idade Média, as criaturas fantásticas como grifos e centauros eram tidas como reais, tanto quanto os leões e javalis, porque pouca distinção era feita entre a observação da natureza e a leitura de bestiários e textos eclesiásticos. Na Cidade de Deus, Santo Agostinho nos conta de homens-monstros, sem bocas, nem olhos e hermafroditas. A arte medieval retratou um mundo deformado, monstruoso, pleno de significado simbólico e alegórico, de acordo com a famosa frase de São Bernardo: "deformisformositas, formosa deformitas". 31

$\mathrm{Na}$ verdade, os animais, reais ou imaginados, sempre foram matéria prima para a arte, desde as pinturas das cavernas. Não somente os artistas neles se motivaram para realizar seus trabalhos, como, mais tarde, escritores, contadores de estórias e naturalistas, procuraram no reino animal uma fonte de estudos e inspiração, de maravilha e fascínio. Os animais têm sido tratados, desde então, como um fenômeno natural a ser objetivamente observado, mas também têm sido investidos com a significação de símbolos sagrados ou como modelos para o comportamento humano

Imagens de animais eram muito comuns na arte da Europa ocidental. Serviam como eficientes recursos didáticos no ensino da cristandade. A necessidade da fácil compreensão das imagens favorecia a conformidade às normas e convenções mais do que a individualidade e a invenção. $\mathrm{O}$ artista medieval era um artesão, trabalhando anonimanente sob o sistema das guildas. A habilidade artesanal era desejada; o desvio das regras não.

As gárgulas foram uma exceção. Representavam uma das poucas áreas na arte medieval em que se permitia ao artista uma considerável licença e liberdade de expressão. Gárgulas eram elementos escultóricos figurativos e grotescos, que ornamentavam canos salientes de escoamento das águas da chuva, nos beirais ou cimalhas das igrejas e catedrais, especialmente as do período gótico da Europa ocidental.

31 LORENZI, Lorenzo. Devils in Art: Florence, from the Middle Ages to the Renaissance, Florence, Centro Di dellaEdifimi, 1997, p. 26. 
Seres humanos e animais figuravam juntos nessas bem humoradas representações medievais, que misturavam num só corpo escultórico, bodes diabólicos e mulheres sorridentes, de uma sensualidade rude e que emergiam das sombras de algumas paredes laterais das igrejas e catedrais. O repertório formal da maioria das gárgulas se constituía de bestas bizarras, desconhecidas e desprovidas de nome e identificação. As gárgulas conformaram dos mais significativos exemplos da maravilhosa e fantástica fauna medieval, numa época conhecida pela multiplicidade de monstros. É importante ressaltar que esses amálgamas implausíveis não eram produto de uma falta de compreensão ou mesmo do desconhecimento por parte dos artistas daqueles animais reais, que por acaso eles não tiveram a oportunidade de observar diretamente. Antes, tratava-se de compositus, (uma espécie de assemblage, no sentido moderno) que os artistas faziam retirando partes de um animal ou ser humano e juntando com partes de outros animais, de uma forma até então desconhecida da Mãe Natureza. Este método de expandir o repertório das formas da natureza era reconhecido como uma prática da Antiguidade, mas atingiu a máxima popularidade na Idade Média.

Com efeito, a teratologia medieval se ateve ao preceito de que o monstro é um composto de animais diferentes que deve conservar cada membro real e verdadeiro nele mesmo. Um exemplo perfeitamente cabível do receituário dos compósitos de monstros encontra-se no Tratado da Pintura de Leonardo Da Vinci, onde o mestre florentino recomenda:

Já sabes que não podes representar animal algum sem seus membros correspondentes; é, pois, necessário que todos os membros de um monstro tenham semelhança com os membros de qualquer outro animal verdadeiro. Se quiseres que pareça real uma besta imaginária, uma serpente, por exemplo, toma a cabeça de um mastim ou de outro cão qualquer, e nela ponha olhos de gato, orelhas de porco espinho, focinho de lebre, sobrancelha de leão, crista de galo e pescoço de tartaruga. ${ }^{32}$

Um outro significado fundamental do monstro - talvez o mais importante aspecto para um entendimento antropológico do seu sentido mitológico e social - é que

${ }^{32}$ DA VINCI, Leonardo. Tratado de la Pintura, Madrid, Aguilar, 1950. pp. 187 - 188. 
em função do seu caráter híbrido e da sua estranha aparência que combina partes animais com humanas, eles causam confusão e horror por preconizarem uma possibilidade de origem animal, de bestialidade e de linhagem demoníaca. Esta última, consta de textos de demonologia nos quais os demônios são responsabilizados pela paternidade de monstros.

O que comumente se entende por monstro não se relaciona a uma criatura em particular, sendo uma categoria que se estrutura de diferentes formas, de acordo com os diferentes contextos históricos em que se apresenta. Desse ponto de vista, o monstro reveste-se de variados sentidos. Possuidor de inúmeros atributos simbólicos, pode significar o guardião de um tesouro, onde assume o estatuto sagrado, como pode surgir também da simbologia dos ritos de passagem: ele devora o homem velho para que nasça o novo. "Mas, às vezes, a devoração pelo monstro é definitiva: é a entrada dos condenados no inferno, mordidos e devorados pelas goelas assustadoras de demônios ou bestas selvagens". 33

Durante a era cristã, o poder expressivo dos animais talvez tenha chegado ao ápice nos bestiários Latinos dos séculos XII e XIII. Os bestiários eram livros feitos pelos monges cristãos, que os copiavam obstinadamente, combinando observações factuais e realistas da vida animal com lendas vigentes, que serviam como textos alegóricos e didáticos na instrução do clero e dos leigos. A impressionante diversidade dos animais gerou ilustrações e promulgações de alertas contra o mau comportamento e o demoníaco. No pensamento medieval, o reino animal era um meio de melhor conscientizar a condição humana do indivíduo e o seu lugar no universo. Servia como uma lembrança constante da unidade do homem com Deus e suas criações. A vida animal era uma fonte de conhecimento e informação que poderia ser utilizada na instrução religiosa. Um exemplo seria o texto do Pseudo-Hugo de São Vítor, que de acordo com a tradição, dedica-se em grande parte a instrução religiosa por meio de sermões. O leitor é repetidamente alertado contra o Demônio e os seus ardis; e diz-se que, tanto os truques do Demônio quanto ele próprio, podem ser reconhecidos em muitos animais, especialmente o macaco, a raposa, o lobo, o asno, a perdiz, o dragão, e a baleia. Às vezes, o autor se encontra pregando contra os Sete Pecados Capitais. Ele

33 Chevalier, Jean. Dicionário dos Símbolos, Livraria José Lympio Editora S.A., Rio de Janeiro, 1998, p. 615. 
torna o crocodilo um exemplo do orgulho, a víbora, da luxúria, e a perdiz, da cobiça; e, mais sutilmente, ele aborda a gula, enfatizando a abstinência alimentar e exemplar do leão (o príncipe de todos os animais, um símbolo muito poderoso). ${ }^{34}$

A figura do dragão (draco) no bestiário se relaciona à do Demônio. O dragão, geralmente voa ao sair do seu covil, e o ar em torno de si é cheio de chamas. O Demônio, por sua vez, ao elevar-se das regiões baixas, transforma-se num anjo de luz e engana os tolos com falsas esperanças de glória e bem-aventurança terrena.

O Demônio também guarda uma similitude com o lobo (lupus): ele está sempre a olhar a raça humana com maldade e sempre à espreita de uma oportunidade para atacar os rebanhos de ovelhas da fé, de maneira a afligir e arruinar suas almas.

A raposa (vulpis), um animal fraudulento e esperto, nunca caminha direto a sua vítima. Quando está faminta e não existe nada para comer, ela se esfrega na lama vermelha para parecer manchada de sangue. Depois, se atira ao chão e prende a respiração. Os pássaros, achando que ela está morta, se aproximam e nela sentam, quando então são atacados, mortos e devorados. O Demônio é da mesma natureza.

O escritor medieval não foi, é claro, o primeiro a atribuir características humanas aos animais nem a investi-los de um simbolismo sagrado. À parte de todo o longo histórico que remonta ao tempo das cavernas, passa por Heródoto, no século V ac, e pelo Historia animalium, de Aristóteles, um século mais tarde, foi Plutarco, o famoso biógrafo e moralista grego, do século II dc, quem primeiro escreveu sobre o simbolismo animal num contexto teológico.

Mas o modelo mais imediato para o bestiário latino foi um tratado moral sobre os animais, escrito por um autor que, acredita-se, tenha vivido em Alexandria, Egito, no século II, e que é conhecido somente por o Physiologus (o Fisiologista). O seu livro sumarizou e codificou o conhecimento e as crenças dos antigos relacionadas a pouco menos de cinqüenta dos animais da terra, pássaros e répteis; dele também foram extraídos ensinamentos morais para o cristão. A tradução latina do Physiologus estava

\footnotetext{
${ }^{34}$ De acordo com o texto, os leões se abstêm de alimentar-se em demasia. Eles só se alimentam e saciam a sede em dias alternados, e quando comem mais do que o necessário, colocam suas patas, cuidadosamente, dentro da garganta e, de acordo com seu próprio juízo, retiram a quantidade excedente de carne.
} 
em circulação muito provavelmente no século IV, e era certamente conhecida no século VI, data em que a identidade do autor foi perdida.

Os compiladores dos bestiários foram mais cuidadosos do que os artistas que os ilustravam, ou que executavam os ornamentos esculpidos nas igrejas. Em 1125, São Bernardo de Clairvaux fez veementes protestos contra os "monstros ridículos" que ele tinha visto quando visitou algumas igrejas - de bestas com rabos de serpentes, a corpos de cavalos misturados com partes de outros animais. Isto era, muitas vezes, o reflexo das incertezas que aconteciam no sistema de classificação dos ilustradores dos bestiários. Todas as vezes que tinham que ilustrar um animal qualquer que não lhes fosse familiar, ou que não houvessem compreendido bem, os ilustradores recorriam a um repertório imaginário de bestas fantásticas, ou então desenhavam o animal de forma incorreta.

Não se pense, entretanto, que as ilustrações dos bestiários tiveram uma ampla influência sobre as artes da escultura, dos vitrais e da pintura. Contrariamente ao pensamento comum, a tradição dos bestiários permaneceu praticamente restrita ao campo da arte da ilustração de livros; suas representações serviam para a produção de outros textos e iluminuras, ilustrações e ornamentações de livros. O argumento principal para tanto é que, na época em que foram feitos os primeiros bestiários, já existiam representações de temas relacionados, como animais e seres fantásticos, nos lintéis e nas colunas das catedrais da França, Itália, Alemanha, Espanha e Inglaterra ${ }^{35}$.

Os bestiários caíram em desuso depois de constatar-se de que não se baseavam numa verdadeira ciência natural, e com o advento de uma pintura mais naturalista, dos séculos posteriores.

Em termos das figurações dos demônios nas obras de arte podem-se estabelecer as seguintes categorias de forma cronológica: ${ }^{36}$

${ }^{35}$ SCHRADER, J. L. Op., cit, p. 8.

${ }^{36}$ LORENZI, Lorenzo. Devils in Art. Florence, from the Middle Ages to the Renaissance, Florença, Centro Di della Edifimisrl, 1997, p. 125. 


\begin{tabular}{|c|c|}
\hline $\begin{array}{l}\text { Demônios-Macacos - século XI ao } \\
\text { século XIII }\end{array}$ & $\begin{array}{l}\text { É a mais antiga família, proveniente da Roma } \\
\text { arcaica, metamorfoseou o sátiro em Satã. }\end{array}$ \\
\hline $\begin{array}{l}\text { Demônios-Répteis - século XII ao } \\
\text { século XIV }\end{array}$ & $\begin{array}{l}\text { Esta é a família mais comum representada na } \\
\text { arte Romanesca. De origem Bizantina-oriental } \\
\text { a iconografia deriva da narrativa da Tentação } \\
\text { no Gênesis. }\end{array}$ \\
\hline $\begin{array}{l}\text { Demônios-Morcegos - século XIV ao } \\
\text { século XV }\end{array}$ & $\begin{array}{l}\text { Esta é a família usual no período de transição } \\
\text { do gótico para o começo da renascença. } \\
\text { Baltrüsaits propõe uma origem chinesa. Na } \\
\text { Itália, Giotto foi o primeiro a usar este tipo } \\
\text { na cena em que São Francisco expulsa os } \\
\text { demônios da cidade de Arezzo no afresco da } \\
\text { basílica de Assisi. Dante representa Lúcifer } \\
\text { no Inferno da Divina Comédia com o atributo } \\
\text { das asas de morcego, três pares a bater-se e } \\
\text { provocar o vento que gela as águas do } \\
\text { Cócito. }\end{array}$ \\
\hline Demônios-Humanóides - século XVI & $\begin{array}{l}\text { È o demônio renascentista por excelência. O } \\
\text { corpo é predominantemente humano com } \\
\text { alguns atributos diabólicos como chifres e } \\
\text { asas de morcego. Luca Signorelli pintou esta } \\
\text { família nos afrescos da catedral de Orvieto. }\end{array}$ \\
\hline $\begin{array}{l}\text { Demônios-Gritadores - do final do } \\
\text { séc. XVI ao final do séc. XVII }\end{array}$ & $\begin{array}{l}\text { É o grupo mais característico da Contra- } \\
\text { Reforma. As representações de demônios } \\
\text { com as bocas abertas e olhos injetados de } \\
\text { sangue eram feitas com o intuito de engajar } \\
\text { as emoções dos espectadores. Michelangelo }\end{array}$ \\
\hline
\end{tabular}




\begin{tabular}{|l|l|}
\hline & utilizou desta iconografia na capela Sistina. \\
\hline
\end{tabular}

Os chifres de bode representavam, no simbolismo cristão, o pecado iníquo que é transformado em impotência. ${ }^{37} \mathrm{O}$ chifre, que evoca o falo, representa a inteligência a serviço dos instintos básicos. Os chifres dos demônios eram de bodes. Bodes eram símbolos do pecado, contrários à ovelha, que representa aquele que é mansamente liderado à morte atento à contemplação de Deus. Consta do Velho Testamento, no Leviticus ${ }^{38}$ que Aarão segurou um bode preto pelas mãos e sobre ele colocou todos os pecados do povo de Israel, mandando-o em seguida para morrer na imensidão do deserto. Com a morte do bode os pecados do povo seriam apagados.

Lobos representavam voracidade e o maligno, os sapos, maldade e raiva, enquanto gafanhotos eram soldados dos exércitos de Satã e algumas vezes simbolizavam os castigos de Deus.

No tocante à utilização das cores, desde o início do século XII os demônios eram usualmente pintados de negro, mas algumas vezes eram azul ou violeta, indicando que eles pertenciam ao reino da escuridão, feitos do ar de baixo, escuro, denso, o oposto dos anjos bons, que eram feitos do fogo etéreo e, portanto, coloridos de vermelho. Outras vezes, eles eram representados de cinza pálido, a cor da doença e da morte. Simbolizava também a impureza. Foi somente na arte medieval tardia que o Demônio era representado na cor vermelha, significando neste caso o sangue ou as chamas do Inferno.

As cores podiam também simbolizar os sete pecados capitais, conforme a seguir $^{39}$ :

${ }^{37}$ LORENZI, Lorenzo. Devils in Art: Florence, from the Middle Ages to the Renaissance, Florence, Centro Di dellaEdifimi , 1997. p. 66.

${ }^{38}$ Leviticus (16,21), Bíblia Sagrada, Edição Barsa, 1965.

${ }^{39}$ LORENZI, Lorenzo, op., cit, p. 124. 


\begin{tabular}{|l|l|}
\hline Demônio preto & O pecado da ira \\
\hline Demônio azul & O pecado do orgulho \\
\hline Demônio marrom & O pecado da gula \\
\hline Demônio verde & O pecado da inveja. \\
\hline Demônio cinza & O pecado da preguiça. \\
\hline Demônio vermelho & O pecado da luxúria. \\
\hline Demônio amarelo & O pecado da avareza \\
\hline
\end{tabular}

Os demônios podem ainda ser classificados pelo lugar onde residem. Nesta categorização, dividem-se em seis gêneros, que são os seguintes, de acordo com o constante em Nogueira: ${ }^{40}$

\begin{tabular}{|l|l|}
\hline Ígneos & $\begin{array}{l}\text { Erram em torno da região superior do ar e não tem nenhum contato com os } \\
\text { homens, pois jamais descem à terra. }\end{array}$ \\
\hline Aéreos & $\begin{array}{l}\text { Rondam pelo ar e estão perto de nós , podem descer e corporificar-se para } \\
\text { aparecer aos homens e perturbam o ar causando tempestades e trovões. Juntos, } \\
\text { preparam a ruína do gênero humano; estão tão cheios de paixões quanto os } \\
\text { homens, principalmente o orgulho e a inveja, e se deixam levar pelas } \\
\text { perturbações. }\end{array}$ \\
\hline Terrestres & $\begin{array}{l}\text { A quem não houve necessidade de precipitar do céu por suas faltas. Uns vivem } \\
\text { nos bosques e florestas e pregam peças aos caçadores; outros, em pleno campo, } \\
\text { levam os viajantes a se perder; o resto, menos furioso, se contenta em habitar } \\
\text { obscuramente entre os homens. }\end{array}$ \\
\hline Aquáticos & $\begin{array}{l}\text { Habitam ao redor de rios e lagos, cheios de cólera... Provocam tempestades } \\
\text { marítimas, submergem as embarcações, fazendo muitos perderem a vida... todas } \\
\text { as vezes que estes demônios tomam a forma visível, aparecem comumente sob a }\end{array}$ \\
\hline
\end{tabular}

46 Sobre a influência da mitologia greco-romana na formação cristã, Junito Brandão, no seu livro Mitologia Grega, Volume I, p.33, nos diz que: "Se, até hoje, muitos estranham e se espantam com 'as múltiplas semelhanças' do culto cristão com 'fatos' mitológicos', isto se deve não apenas à prudente cristianização de significantes da mitologia grega, oriental e romana, mas sobretudo ao Espírito de Deus, que sopra onde lhe agrada. Sob muitos aspectos o Cristianismo salvou a mitologia: dessacralizou-a de seu conteúdo pagão e ressacralizou-a com elementos cristãos, ecumenizando-a”.

40 NOGUEIRA, Carlos Roberto F. O Diabo no Imaginário Cristão. São Paulo, Editora Ática, 1986, p.65. 


\begin{tabular}{|l|l|}
\hline & $\begin{array}{l}\text { forma feminina... As náiades, as sereias e as ninfas, foram nomeadas pelos } \\
\text { antigos no sexo feminino. }\end{array}$ \\
\hline Subterrâneos & $\begin{array}{l}\text { Habitam as cavernas e grutas, são de aparência muito desagradável e atacam } \\
\text { aqueles que cavam poços e minas de metais ou procuram tesouros escondidos. } \\
\text { Sempre estão dispostos a procurar a ruína do gênero humano, seja por fendas ou } \\
\text { abismos, seja vomitando camas, ou pelo desmoronamento de edifícios. Entre } \\
\text { esses demônios, uns são guardiões de tesouros que a malicia dos homens } \\
\text { escondeu na terra e que eles guardam, ocultam e freqüentemente transportam de } \\
\text { um lugar para outro, por medo que voltem de novo ao uso dos humanos. }\end{array}$ \\
\hline Lucifuges & \begin{tabular}{l} 
Assim chamados porque fogem do dia e só podem formar seus corpos à noite. \\
\hline
\end{tabular}
\end{tabular}

Cabe ainda explorar uma representação demoníaca muito usada no medievo e que estava associada à personificação mais comum do mundo inferior, a boca do Inferno, que é a do Demônio devorador, o gigantesco glutão de almas danadas do Inferno. Neste sentido, o Demônio, com sua bocarra escancarada a triturar os pecadores, termina por cumprir a função da boca do inferno, assimilando a sua iconografia.

A goela, símbolo ctoniano ou infernal (análogo à gruta ou à caverna), é “a entrada, portanto, e ao mesmo tempo, a saída das iniciações, tradicionalmente consideradas como digestões: diz-se, aliás, com freqüência, do iniciado escondido no seu retiro, que ele foi 'devorado por um monstro" "41.

A metáfora da enorme boca infernal era também um símbolo constante nos catecismos do século XVIII, como o de Bourges ${ }^{42}$, que diz que "A Terra abrir-se-á e engolirá toda essa infeliz legião de Demônios e de Reprovados, que para sempre irão arder nos Infernos".

Após a devoração demoníaca, acontece a "digestão", quando as almas condenadas incorporam na matéria do Inferno, ou seja, a carne do Demônio.

Um exemplo claro dessa imagem do ventre do Demônio que digere as almas danadas, está numa iluminura medieval, constante no livro de horas do Duque de

\footnotetext{
${ }^{41}$ Chevalier, Jean, Dicionário dos Símbolos, Livraria José Olympio Editora S. A., Rio de Janeiro, 1998, pp. 473.

${ }_{42}$ Trata-se da obra de catecismo da doutrina cristã do abade de Saint-Sulpice, La Chêtardie, na sua edição de 1736, pp. 124-129. Esta informação consta no livro História dos Infernos, de GeogeMinois, Editorial Teorema, LDA, Lisboa, 1997, pp. 266-268.
} 
Berry $^{43}$. Barlowe também inclui no seu Inferno uma ilustração referente a devoração, presente na página $33^{44}$. "Sobre esses temas do dinamismo de repleção e de excreção, funcionam verdadeiras construções de espaço, construções reais ou imaginárias" diz Gaston Bachelard no seu ensaio da terra ${ }^{45}$.

Em termos das fontes pictóricas da boca do Inferno, Link ${ }^{46}$ propõe as pinturas egípcias do devorador dos condenados, Ammit, com suas mandíbulas de crocodilo, pinturas e esculturas clássicas do portão do Hades e a boca da Górgona, que foi talvez a mais influente das três.

A figuração da boca do Inferno no seu aspecto grotesco e literário encontra na obra de Rabelais a sua versão da gastronomia infernal, pois segundo Bakhtin, "no Quarto Livro (cap. XLVI) encontram-se as considerações detalhadas de um diabo sobre os gostos comparados das diversas almas; quais são boas para o café da manhã, para o almoço, e de qual forma devem ser preparadas". ${ }^{47}$ Uma das fontes que Rabelais teria usado para a sua obra foi o poema, de autor desconhecido, intitulado a Salvação do Inferno. Ao herói do poema, "serve-se uma sopa de couves feita com a carne de um usurário, um assado de falsário e o molho de advogado". ${ }^{8}$

Importante ressaltar ainda, com relação ao Pantagruel, que segundo Bakhktin, a grande boca escancarada (garganta e dentes) é uma das imagens centrais do sistema de representações da festa popular, ai incluindo-se máscaras e espantalhos de toda a espécie, além dos demônios das diabruras e até mesmo Lúcifer.

\footnotetext{
${ }^{43}$ A ilustração mostra o Demônio na sua versão monstruosa do Satã medieval, com os atributos típicos da iconografia do início do século XV (corpo peludo, chifres retorcidos, mãos e garras de ave de rapina e coroa), a devorar as almas condenadas que caem no inferno, e, em seguida, a evacuá-las na grelha ardente do fogo eterno.

44 A ilustração mostra uma das criaturas monstruosas, com a aparência de uma ave gigantesca, que primeiro nasceram no Inferno, a devorar uma alma danada. É claramente influenciada pela pintura de Goya intitulada "Saturno a devorar seus filhos". No entanto, esta ilustração representa tão somente um monstro predador a devorar sua presa, um ser infernal a se alimentar de almas danadas, vinculando-se mais ao canibalismo do que a simbologia específica das imagens da boca do inferno.

${ }^{45}$ Bachelard, Gaston. A Terra e os Devaneios do Repouso, Livraria Martins Fontes Editora Ltda, São Paulo, 1990, pp.197.Bachelard nos fornece ainda uma outra referência, desta feita poética ,a esse respeito, na análise feita por Maurice Saillet da obra de Alfred Jarry, onde se evidencia um narcisismo do ventre que digere: "Narciso ignóbil, diz ele, tudo o que existe assume a figura de sua voracidade. A vida é transformada em uma espécie de digestão generalizada".

46 Link, Luther. O Diabo: A Máscara sem Rosto, Editora SchwarczLtda, São Paulo, 1998, p. 89.

47 Bakhtin, Mikhail. A Cultura Popular na Idade Média e no Renascimento: o contexto de Rabelais, Editora Universidade de Brasília, 1996, p. 342.

${ }^{48}$ Ibid, p. 342.
} 
A multiplicidade de existências danadas que habitam o mesmo ventre demoníaco encontra um paralelo na Bíblia ${ }^{49}$, quando Jesus, prestes a exorcizar um homem endemoninhado, pergunta:

"Que nome é o teu?

Ele então respondeu: Legião.

Porque eram em grande número os demônios que tinham entrado nele".

A metáfora da devoração e da digestão dos danados pelo Demônio pode muito bem conformar aquilo que no livro de Bachelard sobre os devaneios da terra, Ernest Fraenkel chama de "a alma gástrica", que é "essencialmente ciclotímica"50. Mas, contrariamente a essa digestão normal e salutar, dia e noite, estômago cheio e estômago vazio, a do Demônio se mostra interminável, pois seu ventre é oco. Está sempre a se encher de almas que aí não permanecem nunca, pois logo são assimiladas ao seu imenso corpo, ao seu sangue, aumentam continuamente o seu tamanho, tornando-o mais e mais faminto. Por isso diz-se que a fome do Demônio por almas é insaciável.

Vale ressaltar que em algumas representações medievais, como por exemplo os infernos de Bosh, o ventre do Demônio é apenas uma passagem para as almas danadas, que logo se precipitam nas profundezas do fogo eterno, após serem excretadas pelo seu ardente ânus. Ou vagina, como é o caso de dois infernos representados no final do século XIV na Itália ${ }^{51}$ :

O afresco da igreja Collegiata de San Gimignano, pintado por Taddeodi Bartolo, no qual as almas são expelidas por uma vagina no formato do que parece ser uma cabeça de sapo, e o afresco executado por Buonamico Buffalmacco no Camposanto, em Pisa, onde o Demônio é representado expelindo um monstro transexual por uma vagina peluda, são imagens fortes e ricas em implicações simbólicas, e que sugerem uma hierarquia corporal semelhante à do realismo grotesco medieval de que fala Bakhtin:

49 Lucas, 8, 30.

50 BACHELARD, Gaston. A Terra e os Devaneios do Repouso, Livraria Martins Fontes Editora, São Paulo, 1990, pp.197.

51 LORENZI, Lorenzo. Devils in Art. Florence, from the Middle Ages to the Renaissance, Florença,Centro Di dellaEdifimi, 1997, pp. 36-41. 
O 'alto' e o 'baixo' possuem aí um sentido absoluta e rigorosamente topográfico. O 'alto' é o céu; o 'baixo' é a terra; a terra é o princípio de absorção (o túmulo, o ventre) e, ao mesmo tempo, de nascimento e ressurreição (o seio materno). Este é o valor topográfico do alto e do baixo no seu aspecto cósmico. No seu aspecto corporal, que não está nunca separado com rigor do seu aspecto cósmico, o alto é representado pelo rosto (a cabeça), e o baixo pelos órgãos genitais, o ventre e o traseiro. $\mathrm{O}$ realismo grotesco e a paródia medieval baseiamse nessas significações absolutas. ${ }^{52}$

Encontrei uma imagem bastante sugestiva dessa digestão demoníaca numa ilustração constante no Livro de Horas da Virgem, escrito em Rouen para Claude I Mole, do final do século XVI, do gênero diableriefrancês. A ilustração mostra um Demônio verde com uma segunda cara na região do ventre, com a boca aberta pronta a devorar mais almas. Dentro da boca figuram diversas almas danadas, prontas a serem evacuadas para o calor das chamas infernais.

No tocante a uma versão literária e grotesca da má digestão demoníaca, cito novamente a obra de Rabelais, Pantagruel, na qual "ele lembra que um dia Lúcifer rompera suas cadeias, e que tivera cólicas atrozes por ter comido no café da manhã um fricassê da alma de um sargento". ${ }^{3}$

Devorador de almas pecadoras, glutão maior do Inferno, rei das sombras e do esgoto, a figuração do Demônio envolveu um vasto complexo de significações históricas, em que as suas variadas designções de Satã, Diabo, Lúcifer e Demônio, articularam um programa iconográfico que possibilitou muitas variações nas suas imagens, fazendo do Demônio o curinga por excelência nas suas representações da arte.

52 BAKHTIN, Mikhail. A Cultura Popular na Idade Média e no Renascimento: o contexto de François Rabelais, Editora Universidade de Brasília, 1996, pp. 18-19.

53 Idem, p.342. 


\section{REFERÊNCIAS BIBLIOGRÁFICAS}

SCHMITT, Jean-Claude \& Jacques Le Goff. Dicionário Temático do Ocidente Medieval . Volumes I e II. Bauru / SP , Universidade Sagrado Coração .

NOGUEIRA, Carlos Roberto. Bruxaria e História. As Práticas Mágicas no OcidenteCristão.São Paulo, Ática, 1991. O Diabo no Imaginário Cristão. São Paulo, Ática, 1986.

LINK, Luther. O Diabo: A Máscara sem Rosto. São Paulo, Schwarcz, 1998.

MUCHEMBLED, Robert. Uma História do Diabo - Séculos XII - XX. Rio de Janeiro, Bom Texto Editora e Produtora de Arte, 2001.

FRANCASTEL, Pierre. A Realidade Figurativa.São Paulo, Perspectiva/USP,1973.

TREVISAN, Armindo. O Rosto de Cristo: A Formação do Imaginário e da Arte Cristã .Porto Alegre, Age, 2003.

FLORES, Nona C. Animals in the Middle Ages. EwYork ,Routledge, 1996.

BALTRUSAITIS, Jurgis. Le Moyen Age Fantastique. Paris, 1955.

LORENZO, Lorenzi. Devils in Art. Florence, From the Middle Ages to the Renaissance. Florence, Centro Di dellaEdifimisrl, 1997.

DA VINCI, Leonardo. Tratado de laPintura.Madrid, Aguillar S. A. de Ediciones,1950.

CHEVALIER, Jean. Dicionário de Símbolos. Rio de Janeiro, José Olympio, 1998.

BACHELARD, Gaston. A Terra e os Devaneios do Repouso.São Paulo, Martins Fontes, 1990.

BAKHTIN, Mikhail. A Cultura Popular na Idade Média e no Renascimento: ocontexto de François Rabelais. Brasília, Universidade de Brasília, 1996. 